\title{
BURNNG THE VELL
}

The Algerian war and the 'emancipation' of Muslim women, 1954-62

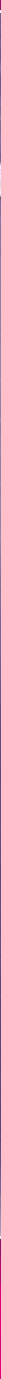


Burning the veil

\section{MANCHESTER 1824}

Manchester University Press 
Neil Macmaster - 9781526146182

Downloaded from manchesterhive.com at 04/26/2023 01:06:28AM via free access 


\section{Burning the veil}

\section{The Algerian war and the 'emancipation' of Muslim women, 1954-62}

NEIL MACMASTER

Manchester

University Press

Manchester 


\section{Copyright $@$ Neil MacMaster 2009}

The right of Neil MacMaster to be identified as the author of this work has been asserted by him in accordance with the Copyright, Designs and Patents Act 1988.

Published by Manchester University Press

Altrincham Street, Manchester M1 7JA, UK

www.manchesteruniversitypress.co.uk

This electronic version has been made freely available under a Creative Commons (CCBY-NC-ND) licence, which permits non-commercial use, distribution and reproduction provided the author(s) and Manchester University Press are fully cited and no modifications or adaptations are made. Details of the licence can be viewed at https://creativecommons.org/licenses/by-nc-nd/4.0/

British Library Cataloguing-in-Publication Data

A catalogue record for this book is available from the British Library

Library of Congress Cataloging-in-Publication Data applied for

ISBN 9780719074738 hardback

First published 2009

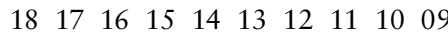
$\begin{array}{llllllllll}10 & 9 & 8 & 7 & 6 & 5 & 4 & 3 & 2 & 1\end{array}$

The publisher has no responsibility for the persistence or accuracy of URLs for any external or third-party internet websites referred to in this book, and does not guarantee that any content on such websites is, or will remain, accurate or appropriate.

Typeset in Sabon

by Servis Filmsetting Ltd, Stockport, Cheshire 